\title{
STUDY OF MACHINING OF THERMAL RECTIFICATED Corymbia citriodora AND Pinus elliottii ${ }^{1}$
}

Luciano Rossi Bilesky², Manoel Cleber de Sampaio Alves ${ }^{3}$, Fábio Henrique Antunes Vieira ${ }^{4}$ and Priscila Roel de Deus ${ }^{5}$

\footnotetext{
${ }^{1}$ Received on 09.02.2017 accepted for publication on 02.01.2018.

${ }^{2}$ Faculdade de Tecnologia em Silvicultura, Ensino Superior da Disciplina de Física, Capão Bonito, SP- Brasil. E-mail: $<$ luciano.bilesky@fatec.sp.gov.br>.

${ }^{3}$ Universidade Estadual Paulista Júlio de Mesquita Filho, Faculdade de Engenharia de Guaratinguetá, Guaratinguetá, SP- Brasil. E-mail:<manoelcsa@feg.unesp.br>.

${ }^{4}$ Faculdade de Tecnologia de Capão Bonito, Ensino Superior da Disciplina de Inglês, Capão Bonito, SP- Brasil. E-mail: <prof_fabio@live.com>.

${ }^{5}$ Faculdade de Tecnologia de Capão Bonito, Ensino Superior da Disciplina Propriedade Físicas da Madeira, Capão Bonito, SP- Brasil, Capão Bonito, SP- Brasil. E-mail: <priroel@hotmail.com>.

*Corresponding author.
}

\begin{abstract}
This study evaluated the influence of thermal rectification in machining Corymbia citriodora and Pinus elliottii. The heat treatment was carried out for 6 hours at temperatures of $100^{\circ} \mathrm{C}, 140^{\circ} \mathrm{C}, 160^{\circ} \mathrm{C}$, $180^{\circ} \mathrm{C}$ and $200^{\circ} \mathrm{C}$ and evaluated the performance of machining in three different material cutting tools, polished and hard metal carbide with TiB2 coating. The cutting power and roughness $R_{a}$ and $R_{t}$ of the machined surfaces with three different tools were evaluated. The power has proven lower for Pinus elliottii species. The roughness was lower for Corymbia citriodora wood. The roughness $\mathrm{R}_{\mathrm{a}}$ and $\mathrm{R}_{\mathrm{t}}$ were lower for heat treatment temperature of $180^{\circ} \mathrm{C}$.
\end{abstract}

Keywords: Heat treatment; Cylindrical turning; Roughness.

\section{ESTUDO DA USINAGEM DAS MADEIRAS DE Corymbia citriodora E Pinus elliottii TERMORRETIFICADAS}

\begin{abstract}
RESUMO - Este trabalho avaliou a influência da termorretificação na usinagem das madeiras de Corymbia citriodora e Pinus elliottii. O tratamento térmico foi realizado durante 6 h nas temperaturas de $100^{\circ} \mathrm{C}, 140^{\circ} \mathrm{C}$, $160^{\circ} \mathrm{C}, 180^{\circ} \mathrm{Ce} 200^{\circ} \mathrm{C}$. Foram avaliados a potência de corte, e rugosidade $R_{a}$ e $R_{t}$ das superficies torneadas com três diferentes ferramentas. A potência se mostrou menor para a espécie de Pinus elliottii. A rugosidade se apresentou menor para a espécie de Corymbia citriodora. A rugosidade $R_{t}$ e $R_{a}$, se apresentaram menor para a tempertatura de tratamento térmico de $180^{\circ} \mathrm{C}$.
\end{abstract}

Palavras-Chave: Tratamento térmico; Torneamento cilindrico; Rugosidade.

\section{INTRODUCTION}

Some technological methods have been used to modify and acquire important properties in forested wood. Among them, the thermal rectification has been highly exploited.

The wood thermal rectification process consists of subjecting it to temperatures between $100^{\circ} \mathrm{C}$ and $250^{\circ} \mathrm{C}$ for certain periods of time, in order that pyrolysis occurs, which involves some physical degradation of wood components such as hemicelluloses, cellulose and lignina. It will allow new properties to the wood, such as color modification, lower water absorption and enhanced resistance to biological degradation (Confederation of Finnish Industries, 2007).

The changes occurring in the wood through thermal rectification process confer higher added value to it.

Revista Árvore. 2018;42(1):e420119

http://dx.doi.org/10.1590/1806-90882018000100019 
This happen, for instance, with the color changing, in which the wood of reforestation happens to have a similar color to native wood.

Also, those changes in the thermal rectificated wood allow new applications to this material in construction and furniture industry. In the literature is possible to find a number of researches in which the object of study is the physical, chemical and mechanical properties of termal rectificated wood (Brito, 2006). However, there is little information on their behavior to machining processes.

The machining operation involves removing material from a workpiece with the assistance of a tool, in order to give it form. It is a very important and widely used process for wood, because the machining is required to transform raw wood into construction boards, floors, doors, frames, etc (Gonçalves, 2000). In the furniture industry, it is necessary to produce battens, boards, roundwood, among others that are used for the manufacture and assembly of furniture.

Although machining is an ancient operation, much remains to be developed for wood. Several parameters need to be changed to get satisfactory results on wood machining, due to the variability and heterogeneity of the material among the different species.

Thermal rectification is a process in which wood is subjected to temperatures between $100^{\circ} \mathrm{C}$ and $250^{\circ} \mathrm{C}$, inferior to those that can cause degradation of its structural components. Its purpose is to present some different features to their original wood for specific applications, which can be structural, acoustic, and composite, for the preservation of wood and packaging (Brito, 2006).

Studies of thermal rectification wood started in the 1930s. Still it can be considered as a new product, because only in the late 1990s that the manufacturing process has been developed and enhanced to industrial scale (Confederation of Finnish Industries, 2007).

Furthermore, the thermal rectification process causes chemical changes in the wood, which now have higher lignin content, and less cellulose/hemicellulose content due to degradation of polymers in the process (Poubel et al., 2013).

Kocaefe et al. (2010) performed thermogravimetric analysis (mass variation analysis with controlled atmosphere and temperature) in Jack Pine wood in $180^{\circ} \mathrm{C}$, and it allowed to observe that the hemicelluloses are prone to degradation during the heat treatment, while the cellulose and lignin are hardly degraded. The degradation of the hemicelluloses causes the release of organic acids which influence the reduction in hydroxyl $(\mathrm{OH})$ groups and the lignin cleavage. The decrease in hydroxyl groups results in reduced absorption of water by the wood (Moura et al., 2012b).

The extractive content of thermal rectificatedwood is increased when the temperature varies from $120^{\circ} \mathrm{C}$ to $180^{\circ} \mathrm{C}$, and is decreased when the treatment temperature is $230^{\circ} \mathrm{C}$ (Poubel et al., 2013).

Due to chemical alterations of the wood structural composition, the physical properties of thermal retificated wood vary according to the treatment temperature and the used species, as the reduction of its hygroscopicity (Modes et al., 2013), swelling and density, wheneverthe heat treatment temperature is increased (Borrega and Kärenlampi, 2008).

Several studies have pointed out that the thermortification process in wood results in the reduction of important mechanical properties of the material, such as flexural strength, shear and compression. The intensity varies according to the wood species and the temperature of the treatment (Moura et al., 2012a).

Studies have examined the heating impact on the roughness of wood surfaces. It has been reported that the movement and later new arrangement of the crystalline segment of celluloses within wood through heating process, produced roughness decrease (Kilic et al., 2006; Salca and Hiziroglu, 2014). These distinctions in surface may be connected with the decline in wood equilibrium moisture content, posterior to the heat treatment, which extensively transform the wood properties for machining (Palermo et al., 2014).

The machining operation is defined as both a complex and simple process, in which pieces are produced by removing excess material in the form of chips. This is one of its manufacturing methods most commonly used (Kilic et al., 2006).

Machining is defined as a complex and simple process at the same time, in which pieces are produced by removing the excess material in form of chips, and it is one of the most used manufacturing methods (Ferraresi, 1977).

Operating factors during machining correspond to those that can be controlled during operation, as they constitute technological factors related to the characteristics of the used equipment, operations and tools.

Revista Árvore. 2018;42(1):e420119 
The tool used in machining is a major factor influencing the operation due to its material constitution and construction geometry.

Selecting a cutting tool should take into account the factors of the material to be machined, type of operation, conditions and model of the machine, shape and dimensions of the tool, the tool material cost, use of lubricating or cooling system and other machining conditions (Gonçalves, 2000).

The main properties desired in a cutting tool material are high hardness, toughness, wear resistance, compressive strength, shear strength, mechanical properties maintained within high working temperatures, thermal shock resistance, impact and oxidation resistance (chemically inert) (Machado et al., 2011). For wood, the main properties to be observed in the tools are abrasion resistance, toughness, stiffness and oxidation. The tool wear occurs due to the abrasive property of the wood and may result in loss of productivity and quality of machined parts (Gonçalves, 2000).

Carbide tools are applied in about $50 \%$ of machining operations due to its cost, hardness, wear resistance and toughness, and they can be applied at high cutting speeds (Gonçalves, 2000). The coating of carbide tools is very important as it can guarantee superior performance in machining, as well as providing affordable cost to these materials (Machado et al., 2011).

Wood was one of the first materials to be machined due to its availability in the environment. Although it is a widely used material, it is still much to be studied in this area because of its variability. For each process, there are several parameters that affect the machining ingranting quality to the piece (Machado et al., 2011).

Pinus and Eucalyptus wood are the species that make up the bulk of Brazil reforestation, but for the most part, the mechanical processing of these woods is currently carried out empirically, affecting their rational use and limiting the development and competitiveness. It emphasizes the need to apply more efforts in machining research of these species.

Some factors are fundamental in the final quality of machining wood. Anatomical factors, harvesting, preparation for machining, and those corresponding to quality of wood from planting to its arrival at the industry patio are factors that often can not be controlled. They depend on the biological characteristics of the material and others factors related to the pre-machining processes.
Density is a leading indicator of wood quality. The higher the density, the greater the required cutting force, which may be five times higher in denser woods, as it is directly related to wood strength (Gonçalves, 2000). The different directions of the wood grain make it difficult to predict the power and cutting force to be used, as the different positions represent different power and applied force (Costes et al., 2004).

The strength of wood increases with decreasing moisture, because the space between the fibrils is reduced, approaching the cell walls and increasing the rigidity exponentially and consequently the force and cutting power, as well as the tool wear (Koch, 1964).

It is desirable that after the machining process, the wood surface presents the lowest roughness as possible, since in most applications this low parameter is recommended.

The final roughness of a workpiece depends on its application. Many other post processes can be used in order to obtain the desired roughness. Among them, sandingis are widely used for this purpose. The reduction of the roughness of thermally treated wood surfaces by the increase of time and temperature, occurs because of deterioration of fibers with the heat (Korkut, 2010).

During the machining of beech wood (Fagus orientalis) and aspen (Populus tremula) the difference of the surface roughness in different wood cutting directions, the highest roughness is found in the radial direction due to diffusivity of wood for both cases, in different machining conditions; and the lowest roughness in the tangential direction (Kilic et al., 2006). There is an increase in surface roughness for thermal rectificated wood due to the heat treatment in the sanding operation for Eucalyptus with 80 to 100 particle size (Palermo, 2010).

This study aimed to evaluate the behavior of thermal rectificated wood of Pinus elliottii and Corymbia citriodora (former Eucalyptus citriodora) from Brazilian reforestation, subjected to the machining through the turning process.

\section{MATERIALS AND METHODS}

We used Pinus elliottii and Corymbia citriodora wood, commercially purchased in Itapeva, São Paulo state, in a $33 \mathrm{~mm} \times 33 \mathrm{~mm} \times 800 \mathrm{~mm}$ board dimensions. 
These boards were unfolded in samples of cylindrical shape, with a length of $100 \mathrm{~mm}$ and a diameter of 31.5 $\mathrm{mm}$. The length of the samples coincides with the longitudinal direction of the wood fibers.

The tests were performed in the Machining Laboratory of the Department of Materials and Technology in the Engineering Faculty of Guaratinguetá.

The samples were selected from visual classification for thermal rectification and the choice was done for those that did not have any sawing or anatomical defect.

The thermortification was performed in a Quimis vacuum oven - QS19V12 model. The samples of Pinus elliottii and Corymbia citriodora were carefully arranged inside the oven, so that there was no contact between each other. The oven was heated at a rate of $4^{\circ} \mathrm{C} / \mathrm{min}$ until reaching the desired temperature, which remained for a period of five hours for each temperature range. There was no control of the atmosphere conditions.

The heat treatment temperatures used were $100^{\circ} \mathrm{C}$, $140^{\circ} \mathrm{C}, 160^{\circ} \mathrm{C}, 180^{\circ} \mathrm{C}$ and $200^{\circ} \mathrm{C}$. After the treatment time, the equipment was turned off, allowing the material to cool down for a period of 24 hours within the oven.

For the machining tests, a CNC (Computer Numeric Control) by Emco whose characteristics promotes two coordinate axes $(\mathrm{X}, \mathrm{Z})$ work, with power of 440 watts. The variation of rotation is comprised between 50 and 3200 RPM.

For the machining of thermortification wood, 54 $\mathrm{mm}$ of material with a depth of $3 \mathrm{~mm}$ was initially taken along the sample, in order to guarantee its uniformity, so that all the tests have the same initial conditions, as Figure $1 \mathrm{~A}$.

The test was performed on the sample in three different regions, as shown in Figure 1D. The machining sequence first occurs in region $1\left(\mathrm{R}_{1}\right)$ at $18 \mathrm{~mm}$ in length (Figure 1B). Then the head returns to the its starting point and moves to region $2\left(\mathrm{R}_{2}\right)$ for a new machining (Figure 1C), and consequently the same occurs in region 3 $\left(\mathrm{R}_{3}\right)$.

The cutting speed in each region was $175 \mathrm{~m} / \mathrm{min}$ (1800RPM) and the feedrate was $100 \mathrm{~mm} / \mathrm{min}$.

Three tools of different characteristics were used to evaluate the performance for machining of thermal rectificated wood, as carbide tools, polished carbide
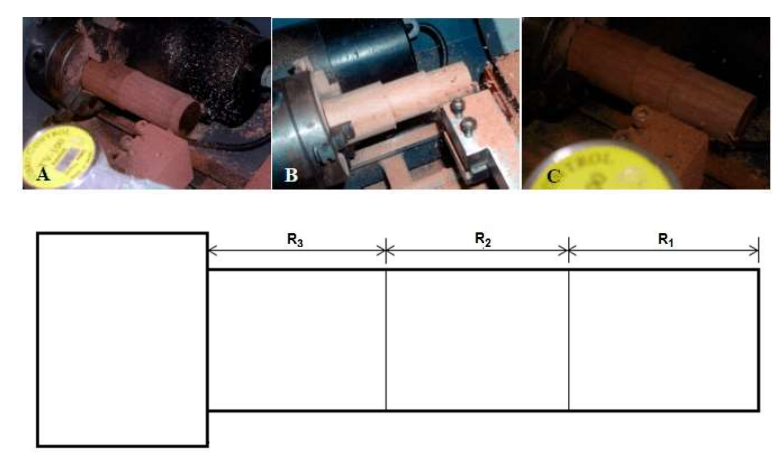

Figure 1 - Machining regions of the sample. A - Region in cylindrical uniformity. B - Machining of region 1 (R1) of the sample. C - Machining of region 2 (R2) of the sample. D - Regions of the sample.

Figura 1 -Regiões de usinagem do corpo de provas. ARegião uniformizada cilindricamente. $B$-Usinagem da região $1\left(R_{1}\right)$ do corpo de prova. $C$-Usinagem da região $2\left(R_{2}\right)$ do corpo de prova. $D$-Regiões do corpo de prova.

and carbide with $\mathrm{TiB}_{2}$ coating, as they have different characteristics and friction coefficients.

For measuring the roughness, it was used a rugosimeter by Mahr, MarSurf M 300 model, with previously defined parameters of $2.5 \mathrm{~mm}$ Cut-Off, Measuring Length of $12.5 \mathrm{~mm}$ and Range of 300ìm. The measurements were carried out randomly, three times in each region of each samples and an average of the values in their respective regions was calculated.

The work was developed based on the Design of Experiments (DOE) methodology, with the application of Taguchi method, which corresponds to an orthogonal matrix that offers an efficient means to perform experiments with the smallest number of trials, instead of a complete factorial. Statistical analyzes were performed using ANOVA.

Factor A corresponds to the heat treatment temperature, and it is divided into 6 levels. Level 1 corresponds to the wood at room temperature without treatment to control; level 2 corresponds to the temperature at $100^{\circ} \mathrm{C}$; in level 3 the temperature treatment was set at $140^{\circ} \mathrm{C}$; level 4 with thermal rectification temperature at $160^{\circ} \mathrm{C}$; level 5 at $180^{\circ} \mathrm{C}$ thermal rectification temperature; and level 6 corresponds to the temperature at $200^{\circ} \mathrm{C}$ of thermal rectification.

Factor B corresponds to the type of wood used. As there were two species, they were divided into two levels: Level 1 Corymbia citriodora wood and level 2 Pinus elliottii wood.

Revista Árvore. 2018;42(1):e420119 
Table 1 - L1 8 mixed matrix used in the tests. Tabela 1 - Matriz L 18 mista utilizada nos ensaios.

\begin{tabular}{ccc}
\hline Factor A & Factor B & Factor C \\
\hline 1 & 1 & 1 \\
1 & 2 & 2 \\
1 & 2 & 3 \\
2 & 1 & 1 \\
2 & 2 & 2 \\
2 & 2 & 3 \\
3 & 1 & 2 \\
3 & 2 & 3 \\
3 & 2 & 1 \\
4 & 1 & 3 \\
4 & 2 & 1 \\
4 & 2 & 2 \\
5 & 1 & 2 \\
5 & 2 & 3 \\
5 & 2 & 1 \\
6 & 1 & 3 \\
6 & 2 & 1 \\
6 & 2 & 2 \\
\hline
\end{tabular}

Factor C corresponds to the type of machine tool, and the level 1 was for carbide tool; level 2 polished carbide tool; and level 3, carbide with $\mathrm{TiB}_{2}$ coating.

The L18 mixed orthogonal matrix, used to carry out the tests, is expressed in Table 1, and represents the amount of samples used in the work.

The data acquisition of the effective power of the $\mathrm{CNC}$ lathe, used in the machining was performed by the HALL effect sensor of the LEM brand and model AT5B10, is constructed in the pliers form and coupled to the motor wires, thus connected a computer, controlled and labored by commercial Labview ${ }^{\circledR}$ software.

\section{RESULTS}

Using Taguchi method, the results obtained from the effective power in relation to thermal rectification temperature, the wood species and the tool used, assuming a significant value for $p$-value at $10 \%$. It can be seen that the wood and tool are significant factors.

In Figure 2 shows the main effects of Mean Effective Power and the main effects from the sinal noise ratio $(\mathrm{S} / \mathrm{N})$ of effective power.

The S/N graph, shown in Figure 2B, emphasizes that in factor B (wood), the level 2 (Pinus elliottii) and in factor $\mathrm{C}$ (tool), the level 3 (coated carbide) are those which present a better $\mathrm{S} / \mathrm{N}$ condition in the relation "smaller is better", as the higher its value, the lower the power required for turning.

In the analysis of surface roughness $\mathrm{R}_{\mathrm{t}}$ using Taguchi method, that the temperature factors (A) and species (B) have a significant p-value at 10\% level in ANOVA.

The graph of the $R_{t}$ average roughness effects from Figure $3 \mathrm{~A}$ shows that in factor $\mathrm{A}$ (temperature) the level $5\left(180^{\circ} \mathrm{C}\right.$ thermal rectification temperature) is the one that has the lowest $\mathrm{R}_{\mathrm{t}}$ roughness, and the species factor, level 2 (Pinus elliottii) is the one that has the lowest $\mathrm{R}_{\mathrm{t}}$ roughness.

As expected, the graph of main effects of $\mathrm{S} / \mathrm{N}$ roughness in Figure $3 \mathrm{~B}$ present inversely proportional to the average graph in Figure $3 \mathrm{~A}$, in which factor $\mathrm{A}$, level 5 has a higher signal/noise ratio as well as factor $\mathrm{B}$, level 2 has a "the lower the better" ratio, evidencing low noise level in the statistical analysis by the taguchi
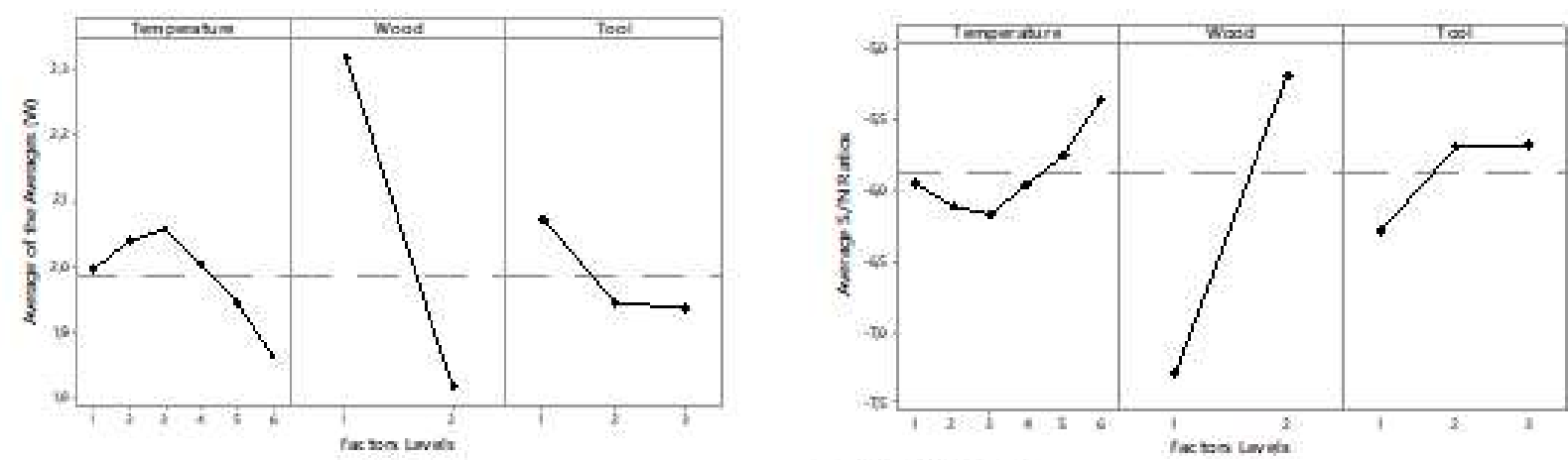

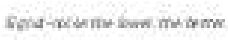

Figure 2 - A - Main effects of Mean Effective Power. B - Main effects from the $\mathrm{S} / \mathrm{N}$ ratio of effective power. Figura $2-A-$ Efeitos principais da potência efetiva. $B$-Efeitos principais da relação $S / N$ da potência efetiva. 

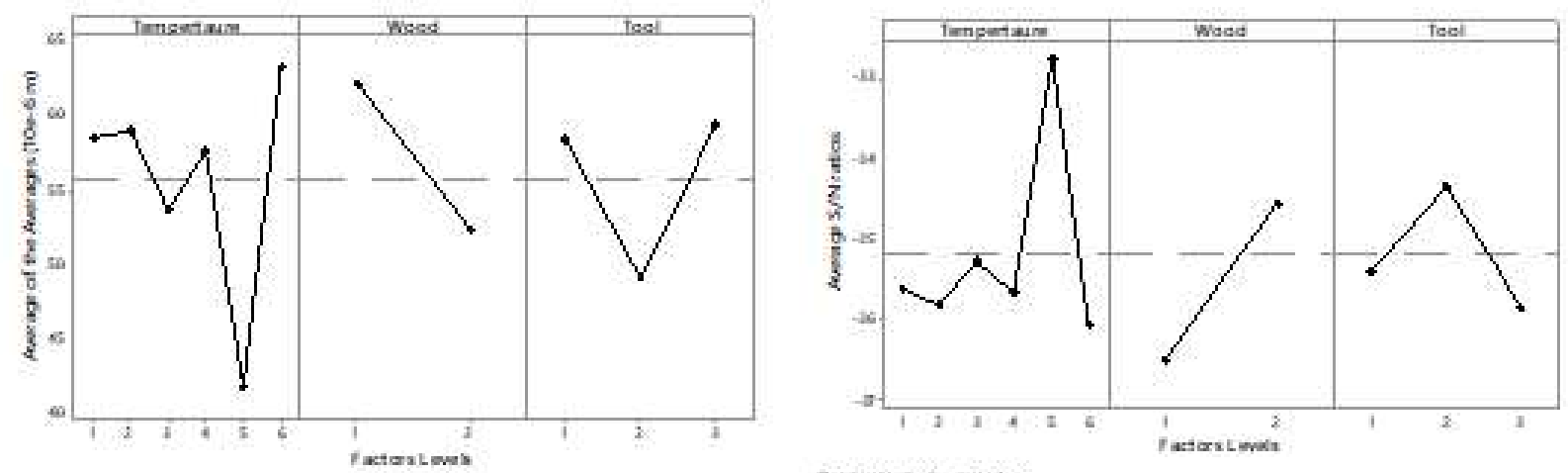

Figure 3 - A - Main effects of the $\mathrm{R}_{\mathrm{t}}$ average roughness. $\mathrm{B}$ - Main effects of the $\mathrm{S} / \mathrm{N}$ ratio of $\mathrm{R}_{\mathrm{t}}$ roughness.

Figura 3-A-Efeitos principais das médias da rugosidade $R_{t}$. B-Efeitos principais da relação $S / N$ da rugosidade Rt.

method, in this way a good response to the results analyzed.

In ANOVA, during the analysis of $\mathrm{R}_{\mathrm{a}}$ roughness using Taguchi method, that the species factor (B) has a significant $\mathrm{p}$-value at $10 \%$ level. The graph of main effects of the average $R_{a}$ roughness in Figure 4A shows that thermal rectification temperature effect in the wood roughness is adverse, but with a tendency to decrease in this parameter $\left(140^{\circ} \mathrm{C}\right)$ to level $5\left(180^{\circ} \mathrm{C}\right)$.

The signal/noise ratio is shown in Figure $4 \mathrm{~B}$, and it is as expected, being inversely proportional to the graph of main effects of the average roughness $R_{a}$ in Figure 4A, evidencing a better signal/noise in factor $\mathrm{B}$ (species) at level 1 (Corymbia citriodora) in "the lower the better" ratio.

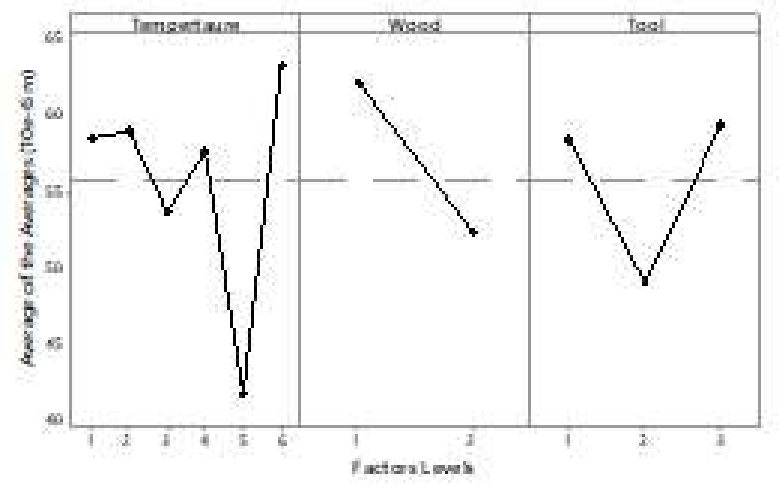

Figure 4 - A - Main effects of the average roughness $\mathrm{R}_{\mathrm{a}}$. B - Main effects of the $\mathrm{S} / \mathrm{N}$ ratio of the roughness $\mathrm{R}_{\mathrm{a}}$. Figura 4 - Efeitos principais das médias da rugosidade $R_{a}$. B-Efeitos principais da relação $S / N$ da rugosidade $R_{a}$.

Revista Árvore. 2018;42(1):e420119

\section{DISCUSSION}

For the main effects of the mean effective power, in Figure 2A, it is highlighted that factor B (wood) in level 2 (Pinus elliottii) required lower effective power for turning. As the cutting force to high-density wood can be as high as five times the required force for lowdensity wood, it explains the fact that the Corymbia citriodora used a higher power compared to Pinus elliottii, since the Corymbia citriodora density is 731,7 $\mathrm{kg} \cdot \mathrm{m}^{-3}$ and Pinus elliottii $355,9 \mathrm{~kg} \cdot \mathrm{m}^{-3}$.

In Figure 2A, factor $\mathrm{C}$ (tool) has a higher required power at level 1 (carbide tool), then Level 2 (polished carbide tool) and the lowest was level 3 (coated carbide tool). This fact is because the lower friction coefficient between the tool and the workpiece due to polishing

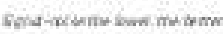

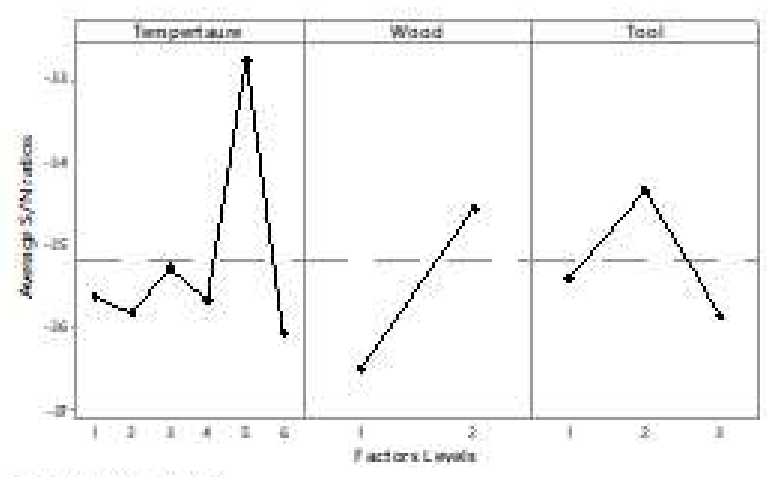

Revista Arvore. $2018 ; 42(1): e 420119$ 
and coating of the tools, reducing this coefficient and consequently, the cutting force (Diniz et al., 2013).

The roughness $\mathrm{R}_{\mathrm{a}}$ depends on the anatomy of wood under study, but it is possible to verify that for Corymbia citriodora wood, the roughness decreases with thermal rectification temperature, because from room temperature to $180^{\circ} \mathrm{C}$, it is noted this attenuation, and also $\mathrm{R}_{\mathrm{a}}$ increased to heat treatment at a temperature of $200^{\circ} \mathrm{C}$. The same effect of $\mathrm{R}_{\mathrm{a}}$ decrease found in Corymbia citriodora up to $180^{\circ} \mathrm{C}$ range and $\mathrm{R}_{\mathrm{a}}$ increase in $200^{\circ} \mathrm{C}$ temperature range, was found in Pinus taeda wood (Salca and Hiziroglu, 2014), in which $\mathrm{R}_{\mathrm{a}}$ roughness before and after thermal rectification was analyzed at temperatures of $120^{\circ} \mathrm{C}$ and $190^{\circ} \mathrm{C}$. The same behavior $\mathrm{R}_{\mathrm{a}}$ roughness was found in East redcedar (Juniperus virginiana) wood for treatment in the same temperature range for eight hours of exposure (Priadi and Hiziroglu, 2013).

For Pinus elliottii wood, $\mathrm{R}_{\mathrm{a}}$ presents an increased value from room temperature to $100^{\circ} \mathrm{C}$ and then a decreased value until the temperature of $180^{\circ} \mathrm{C}$, which is the lowest value found, and soon after an increased value of $\mathrm{R}_{\mathrm{a}}$ to $200^{\circ} \mathrm{C}$ as in Corymbia citriodora, Pinus taeda and Juniperus virginiana (Salca and Hiziroglu, 2014).

The results are as expected because the surface roughness can decrease up to $26 \%$, depending on the wood species and the used heat treatment, combining temperature and exposure time. This happens due to the transition of lignin to a thermoplastic condition, which results in compaction of surface roughness (Korkut, 2010).

\section{CONCLUSION}

Corymbia citriodora wood used more machining power compared to Pinus elliottii wood due to its greater density, which led to higher machining force.

The lower required power was used with the carbide tool covered with $\mathrm{TiB}_{2}$, due to its lower friction coefficient in relation to other tools.

With the heat treatment temperature increasing, the machined wood surface had a lower surface roughness up to $180^{\circ} \mathrm{C}$ temperature range.

Corymbia citriodora wood showed lower roughness compared to Pinus elliottii wood.

The different cutting tools showed no significant changes in the machined surface.
The thermortification in the Corymbia citriodora and Pinus elliottii woods, provide both the machined surface and the machining parameter as a tool used and machining power for each treatment temperature range when compared to the wood without the heat treatment.

\section{REFERENCES}

Borrega M, Kärenlampi PP. Mechanical behavior of heat-treated spruce (Picea abies) wood at constant moisture content and ambient humidity. Holz Roh- Werkst. 2008;66(1):63-9. http:// dx.doi.org/10.1007/s00107-007-0207-3.

Brito JO. Densidade básica e retratibilidade de madeira de Eucalyptus grandis submetida a diferentes temperaturas de termorretificação. Cerne. 2006;12:182-8.

Confederation of Finnish Industries. The nordic recipe for sucessfull innovation. Helsinki: FTA; 2007.80 p.

Costes JP, Ko PL, Ji T, Decès-Petit C. Orthogonal cutting mechanics of maple: modeling a solid wood-cuting process. J Wood Sci. 2004;50:28-34. http://dx.doi.org/10.1007/s10086-003-0527-9.

Diniz AE, Marcondes FC, Coppini NL. Tecnologia da usinagem dos materiais. São Paulo: Art Liber; 2013. 272 p.

Ferraresi D. Fundamento da usinagem dos metais. São Paulo: Edgard Blücher; 1977. 751 p.

Gonçalves MTT. Processamento da madeira. Bauru: Marcos Tadeu Tibúrcio; 2000. 242 p.

Kilic M, Hiziroglu S, Burdurlu E. Effect of machining on surface roughness of wood. Build Environ. 2006;41(8):1074-8. http://dx.doi.org/ 10.1016/j.buildenv.2005.05.008.

Kocaefe D, Poncsak S, Tang J, Bouazara M. Effect of heat treatment on the mechanical properties of North American jack pine: thermogravimetric study. J Mater Sci. 2010;45(3):681-7. http:// dx.doi.org/10.1007/s10853-009-3985-7.

Koch E. Wood maching processes. New York: Ronald; 1964. 530 p. 
Korkut S. Some of the properties of heat-treated Sessile Oak (Quercus petraea). For. Prod. 2010;60:473-80.

Machado AR, Abrão AM, Silva MB, Coelho RT. Teoria da usinagem dos materiais. São Paulo: Blucher; 2011.297 p.

Modes K, Santini EJ, Vivian MA. Higroscopicidade da madeira de Eucalyptus grandis e Pinus taeda tratadas termicamente. Cerne. 2013;19(1):19-25. http://dx.doi.org/10.1590/ S0104-77602013000100003.

Moura LF, Brito JO, Bortoleto G Jr. Efeitos da termorretificação na perda de massa e propriedades mecânicas de Eucalyptus grandis e Pinus caribea var. hondurensis. Floresta. 2012a;42(2):305-14. http://dx.doi.org/10.5380/ rf.v42i2.17635.

Moura LF, Brito J, Silva FG Jr. Efeito da termorretificação nas características químicas da madeira de Eucalyptus grandis W. Hill ex Maiden tratada sob diferentes condições de atmosfera. Cerne. 2012b;18(3):449-55. http://dx.doi.org/ 10.1590/S0104-77602012000300012.
Palermo GPM. Propriedades e comportamento tecnológico da madeira de Eucalyptus grandis W. Hill Ex-Maiden visando a sua utilização em produtos de maior valor agregado [tese]. Seropédica: Universidade Federal do Rio de Janeiro, Departamento de Ciências Florestais e Ambientais; 2010.

Palermo GPM, Latorraca JVF, Moura LF, Nolasco AM, Carvalho AM, Garcia RA. Surface roughness of heat treated Eucalyptus grandis wood. Maderas, Cienc. Tecnol. 2014;16(1):66-73.

Poubel DS, Garcia RG, Santos WA, Oliveira GL, Abreu HA. Efeito da termorretificação nas propriedades físicas e químicas da madeira de Pinus caribea. Cerne. 2013;19(3):391-8. http:// dx.doi.org/10.1590/S0104-77602013000300005.

Priadi T, Hiziroglu S. Characterization of heat treated wood species. Mater Des. 2013;49:575-82. http://dx.doi.org/10.1016/j.matdes.2012.12.067.

Salca EA, Hiziroglu S. Evaluation of hardness and surface quality of different wood species as function of heat treatment. Mater Des. 2014;62:416-23. http://dx.doi.org/10.1016/ j.matdes.2014.05.029.

Revista Árvore. 2018;42(1):e420119 